\title{
Conflict resolution and reconciliation within congregations
}

\begin{tabular}{|c|c|}
\hline \multicolumn{2}{|c|}{$\begin{array}{l}\text { Authors: } \\
\text { Derek L. Oppenshaw }{ }^{1} \\
\text { Malan Nel }{ }^{1} \\
\text { Liebie Louw }^{2}\end{array}$} \\
\hline \multicolumn{2}{|c|}{$\begin{array}{l}\text { Affiliations: } \\
{ }^{1} \text { Department of Practical } \\
\text { Theology, Faculty of Theology } \\
\text { and Religion, University of } \\
\text { Pretoria, South Africa }\end{array}$} \\
\hline $\begin{array}{l}{ }^{2} \text { Department } \\
\text { University of } \mathrm{F} \\
\text { South Africa }\end{array}$ & $\begin{array}{l}\text { f Statistics, } \\
\text { retoria, }\end{array}$ \\
\hline \multicolumn{2}{|c|}{$\begin{array}{l}\text { Research Project Registration: } \\
\text { Project Leader: M. Nel } \\
\text { Project Number: } 02331810\end{array}$} \\
\hline \multicolumn{2}{|c|}{$\begin{array}{l}\text { Description: } \\
\text { This research is part of the } \\
\text { research project, } \\
\text { 'Congregational Studies' } \\
\text { directed by Prof. Malan Nel, } \\
\text { Department Practical } \\
\text { Theology, Faculty of Theology } \\
\text { and Religion, University of } \\
\text { Pretoria. }\end{array}$} \\
\hline \multicolumn{2}{|c|}{$\begin{array}{l}\text { Corresponding author: } \\
\text { Derek Oppenshaw, } \\
\text { derek@methodist.co.za }\end{array}$} \\
\hline \multicolumn{2}{|c|}{$\begin{array}{l}\text { Dates: } \\
\text { Received: } 08 \text { May } 2017 \\
\text { Accepted: } 11 \text { May } 2018 \\
\text { Published: } 06 \text { Sept. } 2018\end{array}$} \\
\hline \multicolumn{2}{|c|}{$\begin{array}{l}\text { How to cite this article: } \\
\text { Oppenshaw, D.L., Nel, M. \& } \\
\text { Louw, L., 2018, 'Conflict } \\
\text { resolution and reconciliation } \\
\text { within congregations', } \\
\text { HTS Teologiese Studies/ } \\
\text { Theological Studies 74(2), } \\
\text { a4641. https://doi.org/ } \\
\text { 10.4102/hts.v74i2.4641 }\end{array}$} \\
\hline \multicolumn{2}{|c|}{$\begin{array}{l}\text { Copyright: } \\
\text { (C) 2018. The Authors. } \\
\text { Licensee: AOSIS. This work } \\
\text { is licensed under the } \\
\text { Creative Commons } \\
\text { Attribution License. }\end{array}$} \\
\hline \multicolumn{2}{|l|}{ Read online: } \\
\hline 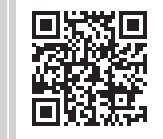 & $\begin{array}{l}\text { Scan this QR } \\
\text { code with your } \\
\text { smart phone or } \\
\text { mobile device } \\
\text { to read online. }\end{array}$ \\
\hline
\end{tabular}

'Being church' in today's world is frought with challenges to traditional practice and contemporaneous opportunities. These challenges, differences, dilemmas and paradoxes, when not handled effectively, have the propensity to escalate into and along a conflict continuum. Conflict can arise at any time within a congregation and needs to be understood and handled theologically. This article addresses some areas within congregations that attract or incubate conflict and provides an overview of related theory of conflict. The research explores current perceptions, understandings and behavioural responses to conflict, personal and corporate experiences and observed outcomes of conflict within congregations. The exploratory study reveals certain disconnects between individual and corporate practice. Congregations in general are biased towards conflict avoidance, peacekeeping and reconciliatory measures - frequently at the expense of long-term resolution. Attaining both resolution and reconciliation appears to be a luxury and not the natural outcome one may expect within Christian fellowship. The perception, understanding and views of most congregants are not aligned to good theological principles and practice. The resultant behaviour mostly observed within congregations does not lead to reconciliation and to a lesser extent resolution. Despite the seemingly high presence of conflict within congregations, no specified education on the understanding, appreciation and handling of conflict in commonly used discipleship resources or dedicated programme was found. The article concludes with a view towards a future praxis of discipleship and leadership, which incorporates the theological understanding and handling of conflict. Broader means of assisting congregations in or post conflict to recovery are also presented.

\section{Introduction}

"“The times, they are a-changing," observed and sung by Bob [sic] Dylan decades ago, continues to be a reality facing the church at the beginning of the 21st century' (Van Gelder in Frost and Hirsch 2009: inside cover). In similar harmony, centuries ago, Charles Wesley penned the hymn: 'A charge to keep I have' (MHB 1972:578). The second verse reads:

\footnotetext{
To serve the present age,

My calling to fulfil:

O may it all my powers engage

To do my Master's will
}

... which speaks of remaining current, serving the 'present age', and calls for 'all my powers' to be engaged in carrying our 'Master's will' in these changing times.

It is within these 'a-changing times' that congregations are found to be 'holding on more tightly to the past as hero', embedding the status quo (Rainer 2014:18); alternatively, 'congregational redevelopment' (Mann 2000:8-12), 'the continual conversion of the church' (Guder 2000:150) or 'congregational reformation' (Nel 2015:205) is embarked upon. Irrespective of which path a congregation intentionally or unintentionally chooses, conflict will arise and 'has to be understood and handled theologically' (Nel 2015:234).

\section{Unrealistic expectations}

Society in general neither understands conflict nor willingly participates in conflict situations. Paradoxically, for Christ followers, scriptures that encourage 'loving one another' (cf. Jn 13:34-35; 15:12-13; Rm 12:8,10; 1 Jn 4:7-8) or 'turning the other cheek' (cf. Mt 5:38-40) or 'do not judge' (cf. Mt 7:1-5; Lk 6:37-42; Jm 4:11-12) create unrealistic expectations of conflict-free congregations.

Note: This article is published in the section Practical Theology of the Society for Practical Theology in South Africa. 
These expectations become barriers to forming realistic perceptions, understandings and responses to conflict.

\section{Critical questions}

Mayer's (2010:3) statements that 'conflict is inevitable' (cf. Lk 17:1, KJV) and 'how it is handled is important' (cf. Nel 2015:234) pose the question: 'How well is conflict handled among congregants, at congregational level toward resolution and reconciliation? How effective are congregations in the resolving of issues and restoration of relationships?' It is imperative that congregations appreciate the potential for conflict during their lifetime and develop effective ways of dealing with conflict (Kale \& McCullough 2003; Shawchuck 1983). How people generally view and understand conflict in turn influences how they react or respond to conflict situations (Mayer 2010:3). People seldom emerge from conflict 'episodes, situations, and concerns' (Osmer 2008:8) with issues resolved and relationships reconciled satisfactorily. Responses to conflict or the handling thereof take on different shapes. The effectiveness of responses is to be assessed by the degree to which it reduces tension between participants, and '... by the short- and long-term effects it will have upon the people and the organisation' (Shawchuck 1983:31).

\section{What is conflict?}

Conflict can simplistically be described as when two pieces of matter, objects or ideas try to occupy the same space at the same time (Bullard 2008:10; Rendle 1998:21), and the process begins when at least one person believes it to exist (Mayer 2010:5). Furthermore, it is '... an interactive process manifested in incompatibility, disagreement, or dissonance within or between social entities (e.g. individuals, a group or organisation)' and is experienced only when one exceeds one's threshold level of intensity, with the level of tolerance being unique to each individual (Rahim 2001:18-19).

\section{Availability of South African resources}

A literature and internet search revealed that much is written on conflict between church leaders and pastors (e.g. Osterhaus, Jurkowski \& Hahn 2005), congregations and pastors' wives (e.g. Ingersoll 2003), churches addressing conflict in their surrounding community (e.g. Lederach 1997) or the church addressing and assisting in conflict situations outside of itself (e.g. The Truth and Reconciliation Commission; The Marakane Crisis). However, there is no readily available work which specifically focuses on conflict 'within the pew', within congregations.

\section{Approach}

In order to explore the forgoing, Osmer's (2008) practical theological approach was used. This approach supports the use of a hermeneutical spiral of four interconnected tasks with intrinsic questions (2008:11), namely:

- Descriptive-empirical task which asks, 'What is going on?' (2008:31-78).
- Interpretive task which asks, 'Why is this going on?' (2008:79-128).

- Normative task which asks, 'What ought to be going on?' (2008:129-173).

- Pragmatic task which asks, 'How can we respond?' (2008:175-218).

Utilising Osmer's questions, literary research focusing on church and conflict (addressing some of the 'what' and 'why') and foundational theory of conflict (addressing some of the 'what' and 'ought') was undertaken. This provided greater understanding, aided the identification of specific survey questions and potential knowledge gaps. Congregants of Methodist Churches in the wider Pretoria areas were surveyed through a quantitative questionnaire. The survey specifically addressed the 'what?' question and to a limited degree also touched some of the 'why'. The section: 'towards future praix' suggests answers to 'how can we respond?' and proposes possible explanations as to the 'why?'

\section{Research objectives}

In attempting to answer the critical questions, this research sought to determine how congregants perceive, understand, respond to, and experience conflict. It was anticipated that such exploratory research would contribute to ministry, point to any related theological concerns or issues and specifically identify further research opportunities.

\section{Conflict and Church}

Contrary to common perception that states, 'Christians don't fight' (Cosgrove \& Hatfield 1994:96), observation and experience find that conflict can arise at any point and time of being, becoming and cultivating church (cf. Nel 2015:234). A few common conflict-related aspects of church life are addressed.

\section{Unfortunate interpretation}

The contemporary use of the term 'church', as a building or place of worship, is a confliction itself as it is far from the origins and truth of the term. In ancient Greece, the ekklesia was the political 'assembly of citizens' (Ac 19:32). The New Testament (Ac 8:1;11:22;13:1) refers to the term as an organised body of believers (Book of Acts, Sproul \& Packer 2001). Hence, Ekklesia 'means both the actual process of congregating and the gathered community itself' (Küng 1978:84). How people as the 'congregating, gathered community' perceive 'church' will influence their actions in being 'church', which will determine what the 'local church' becomes (cf. Callahan 2010:150), that is: who the local church is (Nel 2015:29). Who we are in turn influences what we do and how we behave (Rendle \& Mann 2003:3).

\section{Practice of avoidance}

More than any other institution, the church avoids conflict and confrontation because '... many congregations operate 
with a rule that says "Christians don't fight"' (Cosgrove \& Hatfield 1994:96). Congregations displaying such response or action either try '... to ignore or avoid conflict; or attributes the conflict to a lack of spirituality among its members and then tries to preach and pray it away' (Shawchuck 1983:12). 'Congregations that systematically avoid conflict are also very likely to avoid changing' (Ammerman \& Farnsley 1997:345). Keller (2006:2), on the other hand, encourages leaders to be courageous enough to lead and confront difficult members, despite the fear, the rejection and the unpleasantness that may be encountered. Such unpleasantness is but one of many principle motives that fuel an unwillingness to identify ineffective practices in our churches (Appel \& Nelson 2000:59-62).

\section{Leadership}

The call for strong congregational leadership permeates the work of Guder (2000), McNeal (2009, 2011), Nel (2015), Rendle and Mann (2003) and Van Gelder (2007a; 2007b; 2009), to name a few. Congregational leaders are often unprepared and unsuspecting that 'in a world such as ours, in history as we know it, to choose the path of leadership is to be on a collision course with conflict' (Ford 2008:251).

Fulfilling the calling of being church in this present age (cf. Wesley, in MHB 1972:578) must begin with a responsible, truthful and realistic evaluation and image of its current state (Nel 2015:270), as there is no value in planning for the future if the congregation cannot describe who they are currently and who they have been in the past (Rendle \& Mann 2003:3). As congregations do not enjoy conflict, the most natural response to any current problem is to pretend it is not there or imagine that it will go away and right itself (Mann 1998:39). Articulating the current state and discerning a congregation's future can be a challenging and conflict-producing exercise. This should come as no surprise, because people come into churches from a wide variety of backgrounds that have determined their attitudes, beliefs, values and meaning of church (Kale \& McCullough 2003:13).

\section{Discipleship resources}

The ecclesia is commissioned to 'go and make disciples ...' (Mt 28:19, NIV), yet in contemporary disciple-making, conflict does not feature. Discipleship is not just 'doing courses'; however, the value and use of courses cannot be underestimated. The following courses or programmes commonly utilised in the process of discipleship were perused to determine whether any guidance on conflict handling was evident: An Ordinary Day with Jesus (Ortberg \& Barton 2001); Companions in Christ: A Small Group Experience in Spiritual Formations (Scott et al. 2001); CORE: Following the Master's Plan (Morrell 2003); 3D Ministries (Breen \& Kallestad 2005); Emotionally Healthy Spirituality (Scazzero 2006); Alpha (Gumbel 2009); A Disciple's Path (Harnish 2012); and Journey 101: Knowing, Loving, Serving God (Cartmill et al. 2013). Although some encouraged living out 'the ministry of reconciliation' (2 Cor 5:18), none were found to teach on conflict or provide any assistance on handling conflict. One of the key points surrounding conflict is education from both a theological and sociological perspective; too few people in ministry know anything about how to handle it (Bullard 2008:11; Osmer 2008:10; Shawchuck 1983:50).

\section{Conclusion}

When conflict, 'the number one growth industry for Christian congregations', (Bullard 2008:1) is not responded to promptly or handled well, it can result in unhealthy conflict which has the propensity to destroy the building up (cf. Eph 4:12) of the church (Nel 2015:234-237). Van Yperen's (2002:21) view that 'conflict reveals our faith and character: our willingness or refusal to be the body of Christ' is an encouragement towards leading and handling conflict well.

\section{Foudational theory of conflict}

Statements such as 'Conflict is both good and necessary' (Osterhaus et al. 2005:14) or 'Every congregation needs a little conflict' (Bullard 2008:8) seem contradictory to 'pew' held philosophies. Some theories on conflict as normal and necessary (Lederach 1995:16-17), conflict is not sinful (Sande 2004:30), conflict should not be avoided (Galvin \& Brommel 1982:177) and peacekeeping is not helpful (Sande 2004:11; Sande \& Moore 2005:19) seem inconsistent against Christian thought and popular beliefs that Christian congregations should not experience conflict (Cosgrove \& Hatfield 1994:42).

\section{Normalcy and necessity of conflict}

Lederach (1995:16-17) states that the evolving practices of handling conflict presuppose that conflict is unavoidable, natural, normal, all around us and necessary (cf. Ammerman \& Farnsley 1997:343-346; Cosgrove \& Hatfield 1994:42).

'Conflict is inescapable' and is 'both good and necessary because it elicits different points of view, clears the air, and makes it possible to resolve extraordinarily complex issues' (Osterhaus et al. 2005:14). Conflict is very necessary in congregational life for transformation (Ammerman \& Farnsley 1997:345; Strauch 2011:3) and for attaining spiritual maturity and becoming Christlike (Lederach 1995:17). The value of conflict is seen in its corrective, learning capacity (Strauch 2011:3), and its contribution towards continual transformation in personable, social and organisation environments (Lederach 1995:17). Although conflict is normal, not all conflict is healthy, warn Cosgrove and Hatfield (1994:20).

\section{Conflict is neither categorically wrong nor sinful of itself}

If conflict is normal and necessary, can it be categorically wrong or sinful? Irrespective, in the church context, there is a feeling that its presence is inappropriate ( $\mathrm{Nel}$ 2015:234-235). Poirier (2006:14) suggests that we must see parties to a dispute as members of the body of Christ who are caught in the rebellion and bondage of sin, yet, at the same time called to love and serve one another. Poirier (2006:30) clarifies his position by saying that conflict is not necessarily a consequence 
of sin, though it is assuredly a frequent occasion for it. Conversely, Sande (2004:30) believes many causes or reasons for conflict are 'not wrong or right' but 'simply the result of God-given diversity and personal preferences' (1 Cor 12:21-31). Conflict is not sinful, or sin per se, but rather that '...sinfulness in conflict results from the way we behave in conflict, not from the disagreement or tensions between us' (Shawchuck 1983:9). Paul, the Apostle, understood that there could be conflict without sin and he encouraged the people of Ephesus to '.. be angry and do not $\sin ^{\prime}$ (Eph 4:26, NKJV).

\section{Conflict should not be avoided}

There is little reason to avoid conflict, pretend it does not exist, or not confront problem people - as conflict is normal and necessary. Of all the predispositioned responses to conflict (cf. Rahim 2001:28-33), '... the most commonly chosen, is avoidance' (Augsburger 1992:234). Sociologically, avoidance could be read as '... an unconcerned attitude toward the issues or parties involved in conflict' (Rahim 2001:29-30). Unfortunately, ' ... avoiding conflict can lead to further difficulties because the underlying problems causing it haven't been solved' (Galvin \& Brommel 1982:177).

\section{Negative aspects}

However, Wakefield (1987:22-23) observes that when conflict erupts, valuable energy is wasted; relationships can become damaged or destroyed; problems tend to become enmeshed with complications, diversions and roadblocks; creativity wastes away; self-confidence erodes; and God's honour may be attacked by our unchristian behaviour. Hence, Bullard believes that those who promote unhealthy conflict as righteousness should be confronted and dealt with before they destroy churches (Bullard 2008:10).

\section{Peacemaking or conquering genre}

In the 'fight-or-flight,' or 'escape-or-attack' responses (Poirier 2006:37), aggressive responses are used when people are more interested in emerging as the victor in a conflict than preserving relationships (Sande \& Johnson 2011:38-39). Unfortunately, that frequently translates into perceiving conflict of any scope as an obstacle to conquer, which does not easily facilitate resolution and reconciliation (Haugk \& Perry 1988:26). On the other hand, prematurely assuming that peace has been established is a common peace-faking, conflict avoidance measure (Poirier 2006:38). Peacemakers, within the church context, are people who breathe grace, bringing God's love, mercy, forgiveness, strength and wisdom to the conflicts of daily life (Sande 2004:11). Peacemakers do not avoid conflict, do not see conflict as an obstacle to be conquered and rather '... dissipate anger, improve understanding, promote justice, and encourage repentance and reconciliation' (Sande \& Moore 2005:19).

\section{Conflict resolution and reconciliation defined}

Resolution has to do with issues and is associated with solution, accommodation or settling of a problem, controversy or dispute (Moeller 1994:134). At the heart of effective resolution '.. is a set of constructive attitudes and good communication skills. Repeatedly, I find our attitude toward conflict and communication determine the effectiveness of what we do' (Mayer 2010:xii). In the above, resolution is focused towards the issues, whereas authors such as Ramsbotham et al. (2011:31) describe conflict resolution as an overarching term that incorporates conflict management together with peacemaking, peacekeeping and peacebuilding. In this context, conflict resolution would fill the spectrum from prevention to reconciliation. The term 'resolution', for the purpose of this research, is directed towards issues. It needs to be noted that full resolution of conflict only occurs when there is resolution along cognitive, emotional and behavioural dimensions, without exception (Mayer 2010:108).

Reconciliation has to do with relationships and is '... the restoration of friendship and fellowship after estrangement' (Moeller 1994:134). Mayer (2010:231) indicates that such restoration is mostly reliant on the effectiveness of conflict resolution in addressing behavioural, emotional and cognitive dimension. One of the assumptions of this research is that congregations favour reconciliation above resolution or resolving issues.

\section{Leadership and conflict}

'To lead is to struggle. In a world such as ours, in history as we know it, to choose the path of leadership is to be on a collision course with conflict' (Ford 2008:251). Congregational leadership has a higher standard in conflict situations as it seeks spiritual benefits for all stakeholders (Susek 1999:136). One of today's challenges is that 'congregations need to change the way they do things if they want to reach and hold onto the new generations' (Nicholson 1998:xi). Rendle (1998:21) observes that when change is required, more than 'one idea' is needed which produces conflict, the engagement of differences, out of which come energy, motivation, clarity and direction. The common belief that change equals conflict (cf. Ammerman \& Farnsley 1997:345; Lang 2002:22; Rendle 1998:21) is challenged in Brubaker's (2009:110) empirical work. Brubaker contends that 'Where there is change, there is conflict' may be too simple a description. Where there are insufficiently planned changes to the core meaning-making functions and power relationships of the congregation, there is likely to be conflict may be a less memorable phrase ...', which Brubaker believes '... to be a more accurate conclusion'. It is not so much the 'What' but the 'How' of change that creates conflict. Bullard (2008:12) supports such an outlook by encouraging congregations not to be afraid of healthy conflict, but '... welcome it as an opportunity to bring forth positive spiritual and social change to the love of Christ, and the fellowship of the congregation'. Leaders are called to be peacemakers and not peacekeepers. Peacekeepers attempt to sweep things under the carpet, while peacemakers endeavour to sweep issues out the door (Susek 1999:126). 


\section{Conclusion}

The concepts addressed above provide the background or foundations upon which an investigation into 'the pew', the congregation's perceptions and views, responses or reactions and steps towards reaching an outcome is based. The process and results of such exploratory investigation are detailed in the next section.

\section{Empirical research}

The effective handling of conflict towards resolution and reconciliation within congregations is dependent on how people perceive conflict, which in turn influences their behavioural responses and effects the outcome or destiny (cf. Callahan 2010:150; Mayer 2010:3). This process, within congregations, is reliant on the theological understanding of conflict (cf. Nell 2015:350).

\section{Statistical approach}

This research is not aimed at any predefined type or shape of congregations, cultural groups or biographical specificities. Hence, the assumption was made that Methodist Churches of Southern Africa (MCSA), through its diversity of congregations, would be a reasonable representative population for research with the South African context. Clergy representing 80 societies of the MCSA: Limpopo District Retreat in February of 2015 participated in a feasibility study. A limited census established that $95 \%$ of congregations had experienced conflict over the past 5 years. Higher frequencies of conflict were experienced in congregations that (1) have been in existence for more than 8 years, (2) have an established location and buildings of their own and (3) constitute a membership above two hundred. Most conflict originated in small groups, mission and ministry groups, and leadership. Lastly, there was no indication that the frequency and type of conflict experienced within congregations in the Pretoria area and those in other regions of the Limpopo District differed in any way. This confirmed the presence of sufficient conflict in these congregations to support a research of this nature.

\section{Population}

As gleaned from the feasibility study, societies ${ }^{1}$ older than 7 years comprising more than 200 members and owning their own plant within the wider Pretoria area constituted the scope of measure. Congregational leaders, small group members and ministry and mission group participants from these societies were invited to participate.

\section{Sample profile, sampling method}

A study of the biographical profiles of the defined population revealed that the societies comprised three category ranges of black congregant (inclusive of mixed race and Indian people) to white congregant ratios: Category 'A' (black people 1.Methodist term for 'congregations' or 'church'.
$<20 \%$ :white people $>80 \%)$, Category 'B' $(60 \%>$ black people $>40 \%: 40 \%<$ white people < 60\%) and Category ' $\mathrm{C}$ ' (black people $=100 \%$ ). These categories qualified as strata as they are homogeneous within themselves exhibit greater variability among them, and samples of suitable sizes can be selected independently from each (Gupta and Kabe 2011:41). Simple random sampling, as a percentage of the sample population of each stratum, was used to ensure '... that each different possible sample of the desired size has an equal chance of being the one chosen' (Peck, Olsen \& Devore 2015:38). These groupings were never a prerequisite for the research; however, it was thought prudent to include them and explore their possible value add if any.

\section{Survey instrument}

Quantitative research seeks '... to understand the actions and practices in which individuals and groups engage in everyday life and the meaning they ascribe to their experience' through the gathering and analysing of information (Osmer 2008:49-50). The research title and problem questions provided the lenses for the literary research which identified themes to be explored through a questionnaire. Biographical elements were identified through the feasibility study and literary research. Themes in the questionnaire covered experiences, perceptions, understandings, responses, reactions and views on conflict and perceptions, observations and views towards outcomes. Responses to these themes were collected through a series of statements or questions on seven-point Likert scales. The items of measure included a few negatively phrased statements and questions to counter acquiescence bias, which is the tendency for respondents to agree rather than disagree with statements (Biemer \& Lyberg 2003:124). A pilot study was conducted to pretest the questionnaires for deficiencies and revision.

\section{Consent and confidentiality}

The respondents were aware of the aims and objectives of the study and participated freely. In view of the sensitive nature of the research, anonymous self-completion questionnaires of both a paper and electronic type were used. The distribution package contained a note explaining the confidentiality, the goal and purpose of the study together with the questionnaire. These were made available for electronic and manual reception and completion to 330 potential participants. A response of $57 \%$ was received.

\section{Data set management and analysis}

Returns were captured onto an MS Excel spreadsheet, verified and validated before uploading into the statistical analysis system of the University. A post-load validation through a frequency test, followed by the examination of descriptive coefficients summarising the data set into measures of central tendency and variability, or spread was undertaken. Finally, two-way tabled inferential analysis was applied towards interpretation on categorical variables: leadership, education (on conflict) and race. The two-way chi-square hypotheses 
testing on the $5 \%$ level of significance where the test $p$-values indicate associations as highly significant $(p<0.01)$, significant $(p<0.05)$, a tendency $(0.05<p<0.10)$ and no association $(p>0.10)$ (Sandblom 1983:193) was deemed sufficiently appropriate for this research. This test provides a level of association only, not indices of direction or additional strength. The biographical analysis of respondents showed a race ratio of $65 \%$ white congregants to $35 \%$ black congregants; $39 \%$ were in leadership and $39 \%$ had received education, from non-church entities only, in conflict.

\section{Empirical findings}

\section{Perceptions - personal views of respondents}

Despite $72 \%$ viewing the occurrence of conflict as an opportunity to do good, $48 \%$ see conflict as something to avoid, to escape from, while $56 \%$ perceive conflict as an obstacle to be conquered.

Avoidance: There is strong evidence ( $p=0.0151)$ to suggest that white and black congregants have dissimilar views on conflict avoidance. White congregants make up $78 \%$ of those who see conflict as something to avoid.

To conquer: There is a tendency $(p=0.0557)$ for white and black congregants to differ as to whether conflict is an obstacle to be conquered. Seventy-four per cent of congregants who support this view are of the white segment. There is very strong evidence $(p=0.0024)$ advocating that congregants in leadership differ substantially from those who are not in treating conflict as something to be conquered. Seventy-four per cent of those in leadership see conflict as something to be conquered.

Opportunity to do good: A significant difference $(p=0.0187)$ is evinced between leaders and non-leaders in seeing conflict as an opportunity to do good. While $57 \%$ of non-leaders take a negative view, $84 \%$ of leaders positively champion this view. The question arises as to why this philosophy has not translated into more positive outcomes when handling conflict.

Supposition: The collective perceptions reported above do not influence a positive, healthy behavioural praxis that contributes towards conflict resolution and reconciliation within congregations. Unhealthy perceptions and views produce actions and responses (cf. Callahan 2010:150) that can be negatively experienced and do not translate into effective handling of conflict.

\section{Behaviour-individual and corporate}

Choices and decisions made within a conflict situation shape and reflect who we are as a community and as individuals (Kraybill 2001:4).

Personal actions and responses: The research disclosed that $61 \%$ of congregants envisage themselves as being unafraid to address conflict, and $64 \%$ approach those they have a problem with directly, while $73 \%$ indicate a preference towards being a peacemaker. The test for independence returned association with 'leadership' only.

Unafraid: There is evidence ( $p=0.0396)$ advocating a significant difference between leaders and non-leaders in addressing conflict, supported with only $20 \%$ of those who indicate they are unafraid to address conflict in leadership.

Approach directly: The analysed data proposes $(p=0.0851)$ that leaders and non-leaders have a different tendency towards approaching a person they have a problem with. Seventy-four per cent of those in leadership indicate that they approach a person they have a problem with directly.

Peacemaker: The analysis suggests $(p=0.0857)$ that leaders and non-leaders display dissimilar preferences towards being peacemakers, with $82 \%$ of leaders indicating that they prefer being peacemakers.

Supposition: The tendency of leadership to address people with whom they have a problem directly and their preference to be a peacemaker is unfortunately outweighed by their significant bias towards conflict avoidance. Those not in leadership are far less afraid to address conflict, which suggests that when congregants become leaders their responses to conflict become more conservative, less willing to address conflict and more conflict avoidant. This raises a few questions: (1) Do leaders tend to step away from conflict after approaching people they have a concern about? (2) Is the leader's tendency towards preferring to be a peacemaker inhibiting to conflict resolution and reconciliation between the parties? (3) Do leaders fully understand the role of a peacemaker? (4) Is the role of peacemaker being confused with that of peacekeeper as peacemakers do not avoid conflict? (Sande \& Moore 2005:19). Questions to take cognisance of when conflict arises within the congregation.

Corporate actions and responses: Two of the items in the previous section were reworded to address how congregants observed the handling of conflict within congregations.

Avoidance: Fifty-one per cent of congregants recorded that conflict avoidance is practiced within their congregations.

Confronting problem people: The above observation is reinforced through $65 \%$ observing that problem people in their congregation are not normally confronted.

Supposition: These observed responses or actions confirm the commonly held allegation that congregations ignore or avoid conflict (Shawchuck 1983:12). No associations were found through tests for independence.

Behaviour, comparison: individual and corporate: The respondents reported that personally, individually, they are not afraid to address conflict and will address a person directly with whom they may have a problem. The observed corporate behaviour however, is biased towards conflict 
avoidance and not confronting problem people. This suggests that when individuals gather collectively, as a congregation, their behaviour towards conflict tends to change. Individually, congregants are not afraid to address conflict, whereas corporately they practice conflict avoidance. Individually, congregants go directly to the person with who they have a problem yet, corporately they do not.

Conclusion: The recorded disconnect between the reported personal, individual actions and those observed corporately is not healthy. It is a concern that personal behaviour indicates a willingness to handle conflict, and address problem people yet unfortunately, it is the corporate behaviour of avoidance that will result in an unhealthy congregational outcome or destiny (cf. Callahan 2010:150). The corporate observations are indicative of problems in the process of handling conflict and why observed behaviour does not translate into healthy conflict resolution and reconciliation.

\section{Destiny - experiences and observed outcomes}

Destiny is seen though the experiences of individuals and observed outcomes of conflict within congregations.

Personal experiences in a conflict situation: Thirty-seven per cent of the congregants surveyed find facing conflict a negative experience or find difficulty in trusting God during conflict, or place themselves in a combination thereof.

Negative experience: There is evidence of a tendency ( $p=0.0633)$ to suggest that when white and black congregants face conflict, they do not share the same negative experience. Forty-three per cent of the white segment find facing conflict a negative experience, against only $24 \%$ of the black segment. There is also strong evidence $(p=0.0452)$ to substantiate a similar experience between those in leadership and those not in leadership. Forty-eight per cent of leaders, as opposed to only $28 \%$ of those not in leadership, find facing conflict a negative experience.

Trust in God: There is exceptionally strong evidence $(p=0.0060)$ to suggest that those educated in handling conflict and those who have not received any such education do not share the same difficulty in trusting God when in a conflict situation. Eighty-one per cent of those who received education do not find it difficult to trust God. Of the 'not educated' group, 52\% find difficulty in trusting God during a conflict.

Supposition: When leaders experience conflict negatively, it not only adversely impacts attempts at handling conflict but also frequently causes leadership to be tentative in investigating areas of concern or implementing the required change, alignments or principles for organisational sustainability or development (Wakefield 1987:22-23). It is paramount that, as Christ builds his church (Mt 16:18), sustained trust in God is exercised (cf. Nel 2015:18-21).

Observed corporate outcomes: The research sought to determine the prevalence of resolution, reconciliation and what combinations thereof were observed in congregational conflict. Four previously observed outcomes were presented for evaluation, two from a resolution perspective followed by two from a reconciliation perspective; namely that in the congregation (1) conflict issues are normally resolved, (2) when issues are resolved the relationships are not reconciled, (3) relationships are normally reconciled and (4) although relationships may be reconciled, the issues causing the conflict remain unresolved.

Scenario (1) - Twenty-nine per cent of the respondents reported that conflicts within congregations are normally resolved.

Scenario (2) - Sixty-one per cent of respondents indicated that when conflict issues are resolved, the associated relationships are not reconciled.

Scenario (3) - Fifty-one per cent of the respondents reported that relationships are normally restored.

Scenario (4) - Sixty per cent of respondents observed that when reconciliation is realised, unfortunately, the issues causing the conflict remain unresolved.

Supposition: These results indicate that the respondents witnessed the restoration of relationships more than the resolving of the issues. This confirms the assumption that congregations are more inclined to work on restoring relationships than resolving issues (Prager \& Govier 2010:92).

Result for scenarios (1) and (2) translates into only $11 \%$ of the respondents, when questions are presented from a resolving of issues perspective, who witnessed both resolution and reconciliation. Conversely, the findings for scenarios (3) and (4), when questions are presented from a relationship perspective, indicate that $20 \%$ observed both reconciliation and resolution. These low percentages are understandable as $51 \%$ of the respondents previously indicated that corporately, conflict avoidance is common and are an indication that the handling of conflict resolution and reconciliation within congregations do not appear to be effective.

Conclusion: The results suggest that those in leadership and white congregants experience more negativity in facing conflict and that educating congregants on conflict increases the level of trust in God during a conflict situation. This mix together with a conflict avoidance bias are probable contributing factors towards the low observed percentage of both resolution and reconciliation within congregations.

\section{Theological concerns}

As conflict within congregations need to be understood and handled theologically (cf. Nel 2015:230), a few key aspects were measured to ascertain the congregants theological understanding of conflict.

Normalcy and necessity of conflict: The research sought to determine whether congregants perceived a distinction 
between the normalcy and necessity of conflict sociologically (in every life) and theologically (in Christian living and congregational life).

Eighty-four per cent of respondents display a high level of understanding that 'conflict is inescapable' (Osterhaus et al. 2005:14) and 'normal' (Cosgrove \& Hatfield 1994:42) in everyday life. Conflict is deemed as 'necessary' (Lederach 2015:17) by $54 \%$ of respondents. Changing the context for the normalcy and necessity of conflict to Christian living and congregational life, the respective support plunged by almost half, to $48 \%$ and $30 \%$, respectively. There is exceptionally strong evidence $(p=0.0054)$ to support the hypothesis that congregants who received education in conflict and those who did not have a different view as to the normalcy of conflict in Christian living. Sixty-seven per cent of those who received education favour the view that, in everyday Christian living, conflict is normal. There is also significant evidence ( $p$ $=0.0393$ ) to strongly suggest that those in leadership and those who are not differ in their understanding of conflict as a necessary part of congregational life. Seventy-nine per cent of congregants who did not receive any education do not believe that conflict is a necessary part of congregational life.

Supposition - The results suggest that people segregate their Christian living and congregational life from normal everyday life. Theologically, the two responses should be similar. The moment a congregation envisages its life as separate from normal life, it loses its incarnational dimension and potential (Nel 2015:99-106). Encouragingly, leaders and congregants who received education in conflict are more inclined to appreciate the normalcy and necessity of conflict socially and theologically.

Spiritual maturity: Christ followers are called to grow through their discipleship towards spiritual maturity (cf. Rm 5:3-4; Heb 6:1-2; 1 Tm 4:15; Jm 1:2-4). Responses were therefore solicited as to how respondents perceived the relationship between conflict and Christian maturity. The research shows that $67 \%$ of congregants believe that a higher level of spiritual maturity is a catalyst for lowering the occurrence of conflict in congregations. However, 92\% of respondents did indicate that the way people handled conflict could prove that they are disciples of Christ. Although there was no evidence of dependence or association between Christian maturity and the four elected dependent variables, there was very strong evidence $(p=0.0012)$ in support of the premise that black congregations (' $\mathrm{C}$ ' strata) and predominantly white congregations (' $A$ ' strata) differ on whether the way conflict is handled could prove that people are Christ's disciples. Only $66 \%$ of respondents from black congregations supported this premise.

Supposition: There is no scriptural support to suggest that a higher spiritual maturity would lower the levels of conflict in congregations. To the contrary, one finds the '... very pillars of the church; Peter, Paul, Barnabas, Jesus, and many others disagreeing, and experiencing conflict in their relationships'
(Shawchuck 1983:9). 'Conflict reveals our faith and character' (Van Yperen 2002:21); hence, it is not the presence of spiritual maturity that is required, but the manner with which it is lived out when handling conflict that matters (Kale \& McCullough 2003; Shawchuck 1983).

Existence of conflict: The view that all conflict, even among Christians, is as a result of sin of some nature or another is shared by $46 \%$ of respondents. A data trend query indicated that the higher the percentage of black congregants in a congregation, the greater the measured belief that all conflict stems from sin. Fifty-nine per cent of respondents in black congregations (' $\mathrm{C}$ ' strata) support the hypothesis against $41 \%$ of predominantly white congregations ('A' strata). Forty-four per cent of respondents believe that conflict is wrong and should not exist in congregations. There is very strong evidence $(p=0.0363)$ to indicate that those who received education in conflict and those who did not, tend not to share the same belief that conflict is wrong and should not exist in congregations. As many as $52 \%$ of those who did not receive education support the premise, while only $30 \%$ of those who received education do.

\section{Supposition}

The idea that conflict is wrong and should not exist in a congregation is not consistent with conflict defined as normal and necessary. Although there is a view that $\sin$ is at the root of conflict (Poirier 2006:14), the alternate stance understands the existence of conflict through God-given diversity and individual preferences (Sande 2004:30).

The hand of God: Only $42 \%$ of the respondents are reportedly aligned to the possibility that the hand of God is present in some conflict - God influenced, given or created. There is very strong evidence ( $p=0.0055)$ indicating that those in leadership and those who are not have different opinions or experience as to whether the hand of God would instigate conflict. As many as $70 \%$ of those not in leadership do not believe that some conflict is God inflicted, given or created.

\section{Supposition}

It is somewhat disturbing that there is an apparent lack of biblical understanding within the defined population, as the hypothesis for this item is founded on the following: (1) God influenced: Mary falling pregnant with Jesus (Mt 1:18) caused Joseph to '... resolve to divorce her quietly' (Mt 1:19 NIV) (Jamieson, Fausset \& Brown 1961:6). (2) God given: In Genesis, Adam and Eve had a conflict of choice in whether or not to '... eat from the tree of the knowledge of good and evil' (Gn 2:17, NIV), which God had prohibited (Jamieson et al. 1961:19). (3) God created: Jesus' actions in healing people on the Sabbath caused conflict with the religious rulers and for his disciples (Mk 1:21-26; 3:1-5; 6:2-5; Lk 4: 31-35; 6:6-10; 14:1-6; Jn 5:5-9; 9:14) (Jamieson et al. 1961:69).

Conclusion: The theological aspects as reflected in the above discussion would need to be better understood and applied in the handling of conflict for more effective conflict resolution and reconciliation within congregations. 


\section{Towards future praxis}

There is much evidence to suggest that education and training on conflict from both a sociological and theological perspective is vital. Congregations should be taught to understand conflict, taught to respond appropriately to different conflict scenarios and work towards reconciliation in preparation for the potential of facing or handling conflict (cf. Bullard 2008:3; Osmer 2008:10). In Lang's (2002:69) words: 'When we recognise and accept that conflict is a natural event in the life of the congregation, we can learn how to better navigate it.'

The following are proposed towards future praxis, especially by those in leadership.

\section{Osmer's approach}

It is proposed that Osmer's (2008) approach, used as the underlying methodology for this study, which carries tested value in handling difficult issues, should be taught to congregants, workshopped within leadership and applied in everyday life. This could be done through a Sunday series with related Small group resources.

\section{Through discipleship}

An essential element of congregational life is discipleship, or disciple-making, and the literary research highlighted the absence of conflict education in commonly utilised discipleship courses. It is therefore strongly proposed that the handling of conflict needs to form an integral part of the discipleship process and experience. Robinson (2006) gives ground for that need, in that:

no matter how effective our discipleship processes are there will always be some conflict in the body of Christ. One could even argue that conflict is God's tool for rubbing off our sharp edges so that we are able to develop the fruit of the Spirit. In fact, when one looks at the fruit of the Spirit, it is difficult to see how we could develop any of those fruits without it taking place in the context of relationship with others. Conflict needs to be seen as an opportunity for deepening understanding, not as an occasion to leave the church. (p. 119)

Secondly, it is advocated that congregants be encouraged to approach everyday life as a journey of discipleship where conflict is normal and necessary. Furthermore, that spiritual maturity be developed and evidenced through the way conflict is handled (Kale \& McCullough 2003; Shawchuck 1983) within congregations and not the absence thereof.

\section{Leadership training}

The research indicates that people in leadership experience, view and respond to conflict differently to those not in leadership. The responses characterise leaders as more conservative than those not in leadership when responding to, and in the handling of, conflict. It is recommended that leadership training, development and mentorship include theory and praxis to address this biased tendency. Also that leaders be taught and in turn teach others the biblical principles behind the practical methods, and intentionally cultivate unity around that which is being taught (Dever \& Alexander 2005:24).

\section{Awareness of possible cultural differences}

It is suggested that congregations, and in particular their leaders, be fully aware that black and white congregants view and respond to conflict differently. Such differences may become less polarised during and after receiving education on understanding and handling conflict.

\section{Theological concerns}

The theological problems identified emphasise the need that education in conflict for a Christian community be from a theological and not only sociological perspective. The education received in Christian contexts from specialised non-church-related organisations does not include the fundamentals that are important to effectively addressing conflict within congregations (cf. Nel 2015:234).

\section{Wesley's sermon: The catholic spirit}

The scriptural and theological principles in Wesley's sermon (1999) would be of great benefit if it were taught and workshopped in congregations. In 'The Catholic Spirit', Wesley suggests that '... there are significant differences between Christians', and, despite existing conflict, these differences 'must not be weapons of division' (Harrison 2005:52). Wesley reminds one 'that Christians cannot all think alike; and in consequence ... they cannot all act alike' (Holway 1987:391). The crucial pivotal point in the sermon is that:

... he and the Calvinists may differ in their intellectual explanations of the nature of justifying faith, and yet still share the common 'experience' of their hearts cleaving to God through the Son. (Maddox 1992:67)

This he does by calling for introspection quoting 2 Kings 10:15: 'Is thine heart right, as my heart is with thy heart' and '... if it be, give me thine hand' (KJV 1981). The application is that people in conflict should work through the conflict from the common foundation of their relationship with God and love for all (Davis 2004).

\section{Intentional interim ministry}

It is imperative that during or post-trauma, conflict or grief, congregations are sufficiently cared for. Observed experience in many congregations has shown that 'unless conflict is resolved and healthy communication restored prior to the calling of a new pastor, the chances for success of the new pastorate are substantially reduced' (Nicholson 1998:7). "The "Intentional interim ministry" is a specialized ministry which combines an apostolic function with proven consulting experience designed for churches in transition or crisis' (Richardson in Susek 1999:224). The person leading this fixed period ministry 'is a change agent charged with the specific, 
temporary task of guiding a church through a season of healing, reconciliation, and systematic change' (Van Yperen 2002:13). The interim minister is responsible for the process, while the discernment and articulation of the outcome, together with its ultimate implementation, is and must be the responsibility of the congregation, which will be called upon to embody it as it moves into the future (Bendroth 2015:60).

\section{Conclusion}

Congregations should not avoid confronting their challenges for fear of creating conflict. They should rather embrace them, journey with them from both a sociological and theological perspective, in order to become conflict literate (cf. Bullard 2008:12; Kale \& McCullough 2003; Lederach 1997:345; Nel 2015:234; Shawchuck 1983; Van Yperen 2002:21).

It is hoped that this study may contribute in some way for conflict within congregations to become 'the important, healthy and normal field of tension between people who love each other, who so not want to and cannot lose one another, and in this way love serve the Kingdom together' (Nel 2015:236).

\section{Acknowledgements \\ Competing interests}

The authors declare that they have no financial or personal relationships which may have inappropriately influenced them in writing this article.

\section{Authors' contribution}

This is a contribution of D.L.O. towards a PhD in Practical Theology with the University of Pretoria, in the field of congregational development. M.N. was the study leader. L.L. worked on behalf of the Department of Statistics, University of Pretoria.

\section{References}

Ammerman, N.T. \& Farnsley, A.E., 1997, Congregations \& community, Rutgers University Press, New Brunswick, NJ.

Anon, 1981, The Holy Bible: King James Version, Electronic Edition of the Authorized Version, Logos Research Systems, Inc., Bellingham, WA.

Appel, G. \& Nelson, A., 2000, How to change your Church (without killing it), Thomas Nelson, Nashville, TN.

Augsburger, D.W., 1992, Conflict mediation across cultures: Pathways and patterns, Westminster John Knox Press, Louisville, KY.

Bendroth, N.B., 2015, Transitional Ministry Today: Successful Strategies for Churches and Pastors, Rowman \& Littlefield, New York, NY.

Biemer, P.P. \& Lyberg, L.E., 2003, Introduction to survey quality, John Wiley \& Sons, San Francisco, CA.

Breen, M. \& Kallestad, W., 2005, The Passionate Church, David C. Cook Publishing Company, Colorado Springs, CO.

Brubaker, D., 2009, Promise and peril: Understanding and managing change and conflict in congregations, Rowman \& Littlefield, New York, NY.

Bullard, G.W., 2008, Every congregation needs a little conflict, Chalice Press, St. Louis, MO.

Callahan, K., 2010, The twelve keys leaders' guide: An approach for grassroots, key leaders, and pastors together, John Wiley \& Sons, San Francisco, CA.

Cartmill, C., Kirby, M, \& Kirby, J., 2013, Journey 101: Knowing, Loving, Serving God, Abingdon Press, Nashville, TN.

Cosgrove, C.H. \& Hatfield, D.D., 1994, Church conflict: The hidden systems behind the fights, Abingdon Press, Nashville, TN.

Davis, M., 2004, Resources for our church: John Wesley on doctrinal standards and church unity, viewed 13 June 2016, from http://www.depts.drew.edu/tsfac/ resources/wesley.htm
Dever, M. \& Alexander, P., 2005, The deliberate church: Building your ministry on the Gospel, Crossway Books, Wheaton, IL.

Ford, L., 2008, Transforming leadership: Jesus' way of creating vision, shaping values \& empowering change, InterVarsity Press, Downers Grove, IL.

Frost, M. \& Hirsch, A., 2009, ReJesus: A wild Messiah for a missional Church, Hendrickson Publishers, Sydney.

Galvin, K.M. \& Brommel, B.J., 1982, Stages of the conflictual process, Scott, Forseman \& Company, Glenview, $\mathrm{OH}$.

Guder, D.L., 2000, The continuing conversion of the Church, Wm. B. Eerdmans Publishing, Grand Rapids, MI.

Gumbel, N., 2009, The Alpha Course, Alpha North America, Deerfield, IL.

Gupta, A.K. \& Kabe, D.G., 2011, Theory of sample surveys, World Scientific, London, UK. Harrison, N., 2005, Best of all, God is with us: Heartwarming devotions from the life of John Wesley, Wesleyan Publishing House, Indianapolis, IN.

Harnish, J.A., 2004, You Only Have to Die: Leading Your Congregation to New Life, Abingdon Press, Nashville, TN.

Haugk, K.C. \& Perry, R.S., 1988, Antagonists in the Church: How to identify and deal with destructive conflict, Augsburg Books, Minneapolis, MN.

Holway, J.D., 1987, Sermons on several occasions, Moorley's Print \& Publishing, Ilkeston, UK.

Ingersoll, J., 2003, Evangelical Christian women: War stories in the gender battles, NYU Press, New York.

Jamieson, R., Fausset, A.R. \& Brown, D., 1961, Commentary critical and explanatory on the whole Bible, Zondervan Publishing House, Grand Rapids, MI.

Kale, D.W. \& McCullough, M., 2003, Managing conflict in the Church, Beacon Hill Press of Kansas City, Kansas City, MO.

Keller, T., 2006, Leadership and Church size dynamics - How strategy changes with growth, viewed 07 December 2015, from http://webcache.googleusercontent. com/search?q=cache:vw6mvjPHXrgJ:www.livingwatercc.org/images/VarArticles/ ChurchSize2.pdf $+\& c d=1 \& h=e n \& c t=c l n k$

Kraybill, R.S., 2001, Peace skills: Manual for community mediators, Jossey-Bass Inc., San Francisco, CA

Küng, H., 1978, The Church, Search Press, London.

Lang, S., 2002, Our community: Dealing with conflict in our congregation, Augsburg Fortress, Minneapolis, MN.

Lederach, J., 2015, Little book of conflict transformation: Clear articulation of the guiding principles by a pioneer in the field, Skyhorse Publishing, Inc., New York City, NY.

Lederach, J.P., 1995, Preparing for peace: Conflict transformation across cultures, Syracuse University Press, Syracuse, NY.

Lederach, J.P., 1997, Building peace: Sustainable reconciliation in divided societies, United States Institute of Peace Press, Washington, DC.

Maddox, R., 1992, 'Opinion, religion and 'Catholic Spirit': John Wesley on theological integrity', The Asbury Journal 47(1), 63-88, viewed 22 January 2013, from http:// place.asburyseminary.edu/asburyjournal/vol47/iss1/6

Mann, A., 1998, The in-between Church: Navigating size transitions in congregations, Rowman \& Littlefield, New York.

Mann, A., 2000, Can our Church live?, Rowman \& Littlefield, Lanham, MD.

Mayer, B., 2010, The dynamics of conflict resolution: A practitioner's guide, John Wiley \& Sons, San Francisco, CA.

McNeal, R., 2009, Missional renaissance: Changing the scorecard for the Church, 1st edn., Jossey-Bass, San Francisco, CA.

McNeal, R., 2011, Missional communities: The rise of the post-congregational Church, John Wiley \& Sons, San Francisco, CA.

MHB, 1972, Methodist hymn book with hymns and songs, 35th edn., The Garden City Press Ltd., Hertfordshire.

Moeller, R., 1994, Love in action: Healing conflict in your Church, Multnomah Books, Colorado Springs, $\mathrm{CO}$.

Morrell, D., 2003, CORE: Following the Master's Plan for Discipleship, viewed n.d., from http://www.corediscipleship.com

Nel, M., 2015, Identity-driven Churches: Who are we and where are we going? Biblecor, Wellington, South Africa.

Nicholson, R.S., 1998, Temporary shepherds: A congregational handbook for interim ministry, Rowman \& Littlefield, Lanham, MD.

Ortberg, J. \& Barton, R., 2001, An Ordinary Day with Jesus, WillowCreek Resources, South Barrington, IL.

Osmer, R.R., 2008, Practical theology: An introduction, Wm. B. Eerdmans Publishing, Grand Rapids, MI.

Osterhaus, J.P., Jurkowski, J.M. \& Hahn, T.A., 2005, Thriving through ministry conflict, Zondervan Publishing House, Grand Rapids, MI.

Peck, R., Olsen, C. \& Devore, J.L., 2015, Introduction to statistics and data analysis, Cengage Learning, Boston, MA.

Poirier, A.J., 2006, The peacemaking pastor: A biblical guide to resolving church conflict, Baker Books, Grand Rapids, MI.

Prager, C. \& Govier, T., 2010, Dilemmas of reconciliation: Cases and concepts, Wilfrid Laurier University Press, Waterloo, ON

Rahim, M.A., 2001, Managing conflict in organizations, Greenwood Publishing Group, Westport, CT. 
Rainer, T. S., 2014, Autopsy of a Deceased Church: 12 ways to keep yours alive, B\&H Publishing Group, Nashville, TN.

Ramsbotham, O., Miall, H. \& Woodhouse, T., 2011, Contemporary conflict resolution, Cambridge, England.

Rendle, G. \& Mann, A., 2003, Holy conversations: Strategic planning as a spiritual practice for congregations, Rowman \& Littlefield, Lanham, MD.

Rendle, G.R., 1998, Leading change in the congregation: Spiritual and organisational tools for leaders, Alban Institute, Washington, DC.

Robinson, M., 2006, Planting mission-shaped churches today, Kregel Publications, Grand Rapids, MI.

Sandblom, C.-L., 1983, Elementary statistics for business and economics, W. de Gruyter, New York.

Sande, K., 2004, The peacemaker: A biblical guide to resolving personal conflict, 3rd edn., Baker Books, Grand Rapids, MI.

Sande, K. \& Johnson, K., 2011, Resolving everyday conflict, Baker Publishing Group, Grand Rapids, MI.

Sande, K. \& Moore, K., 2005, Peacefakers, peacebreakers, and peacemakers: Leader guide, Hannibal Books, Garland, TX.

Scazzero, P., 2006, Emotionally Healthy Spirituality: Unleash a Revolution in Your Life in Christ, Thomas Nelson, Nashville, TN.

Scott, G., Job., R.P., Thompson, M.J., Wright, W.M., Gonzalez, A. \& Hinson, E.G., 2001 Companions in Christ: A Small-Group Experience in Spiritual Formation, Upper Room Books, Nashville, TN.
Shawchuck, N., 1983, How to manage conflict in the Church: Understanding and managing conflict, Spiritual Growth Resources, Highlands Park, IL.

Sproul, R.C. \& Packer, J.I., 2001, The reformation study Bible: Helping you understand the Bible from a reformation perspective, Thomas Nelson Incorporated, Nashville, TN.

Strauch, A., 2011, If you bite \& devour one another Galatians 5:15: Biblical principles for handling conflict, Lewis and Roth Publishers, Colorado Springs, $\mathrm{CO}$.

Susek, R., 1999, Firestorm: Preventing and overcoming church conflicts, Baker Books, Grand Rapids, MI.

Van Gelder, C., 2007a, The Ministry of the Missional Church: A community led by the spirit, Baker Books, Grand Rapids, MI.

Van Gelder, C., 2007b, The missional church in context: Helping congregations develop contextual ministry, Wm. B. Eerdmans Publishing, Grand Rapids, Ml.

Van Gelder, C., 2009, The missional church and leadership formation: Helping congregations develop leadership capacity, Wm. B. Eerdmans Publishing, Grand Rapids, MI.

Van Yperen, J., 2002, Making peace: A guide to overcoming church conflict, Moody Publishers, Chicago, IL.

Wakefield, N., 1987, Solving problems before they become conflicts, Zondervan Pub. House, Grand Rapids, MI.

Wesley, J., 1999, Sermons, on several occasions, Logos Research Systems, Inc., Oak Harbor, WA. 